\title{
Effect of Water Extracts of some Aromatic and Medicinal Plants on Mortality and Egg Hatching of Root- knot Nematode, Meloidogyne Incognita in Vitro studies
} Maareg, M. F. * A. Y. El- Gindi ${ }^{* *}$; Mona E. El- Shalaby ${ }^{*}$ and Abeer, S. Yassin ${ }^{*}$

* Department of Plant Protection, Sugar Crops, Research Institute, Agriculture Research Center, Giza, Egypt.

** Department of Agriculture Zoology and Nematology, Faculty of Agriculture, Cairo University, Giza, Egypt.

\begin{abstract}
Water extracts of the ten aromatic and medicinal plant namely, Camphor (Eucalyptus globulus), Camphor Lemon (E. citriodora), Demssisa (Ambrosia maritime), Lemon grass (Cymbopgon citratus), Marjoram (Origamum majorana), Neem (Azadrachta indica), Rosemary (Rosmarimus officinallis) and Thyme (Thymus vulgaris) as leaves, Chamomile (Matricaria chamomilla) and Daisy (Calendula officinalis) as leaves and flowers with different concentrations (5, 10 \& $15 \%$ ) of different plants were assessed in vitro against egg hatching and juveniles $\left(\mathrm{J}_{2 \mathrm{~s}}\right)$ mortality of root- knot nematodes Meloidogyne incognita in different durations. Results indicated that eggs inhibition and J2s mortality increased with an increase in the concentration of all the extracts. Similarly, with an increase in exposure time, $\mathrm{J}_{2 \mathrm{~s}}$ mortality was also increased. Water extracts of all plants showed nematicidal effect against $M$. incognita at varying degree. Based on these finding, these plant extracts at the highest concentration (15\%) were divided into 4 main groups i.e. highly toxic ( $>85 \%$ mortality or inhibition), consisting of Demssisa, Camphor Lemon and Thyme, toxic (70 - < 85\%) consisting of Daisy and Marjoram, moderately and lowly toxic groups, consisting of the test plant extracts tested. This finding is important from the point of view of controlling root- knot nematodes without the use of chemical nematicides in view of environmental pollution likely to cause. The use of these plant extracts may be one of the efficient alternatives and cheep methods of nematode control, that are sale to farmers and inurnment. These may be replacement to the synthetic dangerous and expensive chemical nematicides in future.
\end{abstract}

Keywords: Aromatic plant, medicinal plant, in vitro test, Meloidogyne incognita, water extract, eggs hatching, sugarbeet.

\section{Introduction}

Root- knot nematode, Meloidogyne species, are generally known to be the most harmful phytoparasites, because of their worldwide occurrence and the heavy yield losses caused to a large range of agriculture crops (Wesemael et al., 2010). 
The population of plant parasitic nematodes in the field can be minimized through several approaches such as using natural enemies (Maareg et al., 2005a and Khan \& Kim, 2007), enhancing cultural practices (Maareg et al., 2005b \& 2007 and Okada \& Harada, 2007), cultivating resistant cultivars (Williamson \& Kumar, 2006) and applying chemical nematicides. Application of these pesticides have been found as an effective measure for the control of nematodes, but due to its high toxic residual effect and toxicity of these chemicals to beneficial flora and fauna in the soil there is therefore need to develop an alternative nematode control strategies. One of the outstanding alternative control measures against nematode pests is the application of plant extracts. Numerous plant extracts have been reported to suppress root- knot nematode population (Ibrahim et al., 2006; El-badri et al., 2008; Mousa et al., 2011; Salim et al., 2016 and Youssef et al., 2015). Analysis of these plants showed that capability of non- toxic metabolites is the best alternative strategy for controlling nematodes but use of compounds and secondary metabolites of plants was limited (Khayyat et al., 2014).

Use of plant and their products is one of the safe methods to control rootknot nematodes. These methods are low cost, easy to apply and also have the ability to improve soil texture and fertility.

The objectives of this work, to evaluate the nematicidal effect of the water extracts of ten aromatic and medicinal plants on mortality and eggs hatching of second stage juveniles $\left(\mathrm{J}_{2 \mathrm{~s}}\right)$ of root- knot nematode, M. incognita in vitro studies.

\section{Materials and Methods}

\section{Plant materials:}

The ten aromatic and medicinal plant species, and their scientific, family, common, arabic names and part of the plant used for extraction are presented in Table, 1.

\section{Preparation of extract:}

The aqueous plant extracts were prepared as follows, the test plant leaves and flowers (Table, 1) were collected, washed and dried in laboratory condition. After drying, plants were separately powdered using an electric grinder and 5, 10 and $15 \mathrm{~g}$ powder of each plant powder were mixed separately in $100 \mathrm{ml}$ of distilled water in aluminum foil covered $500 \mathrm{ml}$ flasks. These flasks were then placed into shaker with the idle speed for 24 hours at laboratory temperature. After $24 \mathrm{hrs}$, the contents of the flasks were passed from muslin cloth, and then it was filtered through $15 \mathrm{~mm}$ diam. Whatman No. 1 filter paper to get the clear extract. Obtained filtrained filtrates were used as 5, 10 and $15 \%$ concentrations for each plant extract.

\section{Effect of water plant extracts on juveniles mortality:}

The tested root- knot nematode species, $M$. incognita, was harvested according to the method as described by Barker, (1985). 
Table (1): The scientific, family, common arabic names and plant parts that were extracted for ten aromatic and medicinal plants tested

\begin{tabular}{|c|c|c|c|c|}
\hline Scientific name & $\begin{array}{l}\text { Family } \\
\text { name }\end{array}$ & Common name & $\begin{array}{c}\text { Arabic } \\
\text { name }\end{array}$ & Part used \\
\hline Ambrosia maritime L. & & Demssisa & دمسيسة & Leaves \\
\hline Calendula officinalis L. & $\begin{array}{l}\text { Asteraceae } \\
\text { (Compositae) }\end{array}$ & Daisy & 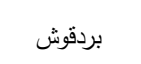 & Leaves flowers \\
\hline Cymbopgon citratus L. & & Lemon grass & حشبشة ليمون & Leaves \\
\hline Azadrachta indica L. & Meliaceae & Neem & نيم & Leaves \\
\hline Eucalyptus citriodora L. & & Camphor Lemon & كافور ليمون & Leaves \\
\hline Eucalyptus globulus L. & Mlyrtaceae & Camphor & كافور بلدى & Leaves \\
\hline Matricaria chamomilla L. & $\begin{array}{c}\text { Poaceae } \\
\text { (Gramineae) }\end{array}$ & Chamomile & شيح بابونج & Leaves flowers \\
\hline Origamum majorana L. & & Marjoram & أقحوان & Leaves \\
\hline Rosmarimus officinallis L. & Lamiaceae & Rosemary & 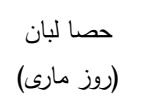 & Leaves \\
\hline Thymus vulgaris $\mathrm{L}$. & & Thyme & زعتز & Leaves \\
\hline
\end{tabular}

To detect the effect of plant extracts against the mortality\% of the second stage juveniles $\left(\mathrm{J}_{2 \mathrm{~s}}\right)$ of $M$. incognita. The $\mathrm{J}_{2 \mathrm{~s}}$ suspension was adjusted to $100 \mathrm{~J}_{2 \mathrm{~s}}$ per $\mathrm{ml}$. Nine $\mathrm{ml}$ of each concentration of plant extract of each plant were added to $1 \mathrm{ml}$ of $\mathrm{J}_{2 \mathrm{~s}}$ suspension in Petri dish. Also, nine $\mathrm{ml}$ of distilled water were added to $1 \mathrm{ml}$ of $J_{2 s}$ suspension in the Petri dish for the control treatment. The numbers of live and dead nematodes were counted under light microscope after 24, 48 and 72 hrs of exposure periods to tested plant materials at $25^{\circ} \mathrm{C}$. From these counts, the percentage of nematode mortality was calculated for each treatment. The corrected nematode mortality percentages were calculated according to Abbott (1925).

\section{Effect of water plant extracts on egg hatching:}

This study was carried out to determine the effect of different concentrations of water plant extracts on hatching of $M$. incognita eggmasses under in vitro conditions. Root- knot nematode infected tomato plants from pure culture pots were up- rooted and washed gently under running tap water. Eggmasses of $M$. incognita were picked up from tomato roots using dissecting needle and forceps. Uniformly sized eggmasses used and transferred to Petri dishes (one eggmass/ Petri dish). Ten $\mathrm{ml}$ of each concentration of water plant extract of each plant were added to one eggmass in Petri dish. Eggmass in ten of distilled water was only served as control treatment. The number of juveniles hatched after three days exposure to different concentrations and distilled water were caunted under light microscope, and mean juveniles hatched was calculated.

All tested Petri dishes containing the suspension and the eggmasses kept at room temperature on laboratory bench in completely randomized design with four 
replications for each treatment. Data were subjected to analyses of variance and means were compared using LSD at 0.05 according to Gomez and Gomez, (1984), followed by Duncan's multiple range tests to compare means (Duncan, 1955).

\section{Results and Discussion}

The nematicidal activity of water extracts of ten aromatic and medicinal plants (Table, 1) were evaluated with different concentrations against $M$. incognita $J_{2 s}$ mortality and eggmass hatching in vitro studies, and the obtained data tabulated in Tables 2 and 3 .

\section{Against juveniles mortality:}

The results of nematicideal activity of water extracts of tested aromatic and medicinal plants with 5, 10 and $15 \%$ concentrations after 24,48 and 72 hours of exposure periods on mortality of $M$. incognita $\mathrm{J}_{2 \mathrm{~s}}$ are given in Table (2). It was obvious that there a significant $(P \leq 0.05)$ differences among tested treatments. The least mortality percentage $(1.3 \%)$ of $\mathrm{J}_{2 \mathrm{~s}}$ of $M$. incognita was observed with control (distilled water) 24 hours after treatment application, while, the highest mortality percentage $(94.1 \%)$ of $J_{2 s}$ was seen at highest concentration (15\%) with Demssisa leaves extract 72 hours after treatment, compared to all the other treatments. The percentage of viability or mortality of the second stage juveniles $\left(\mathrm{J}_{2 \mathrm{~s}}\right)$ was affected by plant species (type) and their concentrations as well as exposure time. In general, the mortality percentage increased with the progressive increase in concentration and/ or in time of exposure in each plant extract.

After 24 hours of exposure, all water extracts of test plants were effective in causing larval mortality. The mortality rate was found to differ significantly $(P \leq 0.05)$ among different concentrations of water extracts of tested plants. The highest concentration i.e. $15 \%$ of extracts being more efficacious and show high significant $(P \leq 0.05)$ differences than the other concentrations (10 and $5 \%)$ and there was a significant difference between them in all plant extracts tested. The rate of mortality was directly proportionate to concentrations of each extract. The highest mortality rate of $\mathrm{J}_{2 \mathrm{~s}}$ was observed at highest concentration (15\%) and the lowest one was observed at lowest concentration (5\%) within all water plant extracts under study. The different concentrations i.e., 5, 10 and 15\% of Damssisa leaves extract were more effective in causing $\mathrm{J}_{2 \mathrm{~s}}$ mortality, when compared to the same concentrations of all the other plant extracts within 24 hours of exposure treatment. At $15 \%$ concentration of plant extract application, the highest $J_{2 s}$ mortality\% (65.1\%) was shown in Demssisa leaves extract, followed by Camphor lemon leaves extract (64.3\%, Daisy leaves and flowers extract (48.9\%) and Thyme leaves extract $(45.8 \%)$, respectively, however, the lowest $\mathrm{J}_{2 \mathrm{~s}}$ mortality $\%$ at the same concentration was shown in both chamomile leaves \& flowers and Rosemary leaves extracts with an average 17.0 and $16.25 \%$ of $\mathrm{J}_{2 \mathrm{~s}}$ mortality, respectively. 
Table (2): Effect of water extracts of some and medicinal plants with three concentrations on second stage juveniles of root- knot nematode, Meloidogyne incognita after 24, 48 and 72 hours of exposure period in vitro tests.

\begin{tabular}{|c|c|c|c|c|c|c|c|c|c|c|}
\hline \multirow{3}{*}{$\begin{array}{l}\text { Aromatic and medicinal } \\
\text { plants }\end{array}$} & \multicolumn{4}{|c|}{24 hours } & \multicolumn{3}{|c|}{48 hours } & \multicolumn{3}{|c|}{72 hours } \\
\hline & & \multicolumn{9}{|c|}{ Concentrations \% } \\
\hline & & 5 & 10 & 15 & 5 & 10 & 15 & 5 & 10 & 15 \\
\hline $\begin{array}{c}\text { Camphor } \\
\text { (Eucalyptus globules) }\end{array}$ & & 10.6 & 19.5 & 38.7 & 15.3 & 23.7 & 43.4 & 22.0 & 34.4 & 56.1 \\
\hline $\begin{array}{l}\text { Camphor lemon } \\
\text { (Eucalyptus citriodora) }\end{array}$ & & 41.0 & 56.5 & 64.3 & 55.9 & 67.1 & 79.3 & 62.8 & 74.9 & 89.7 \\
\hline $\begin{array}{c}\text { Chamomile } \\
\text { (Matricaria chamomilla) }\end{array}$ & & 7.1 & 12.9 & 15.9 & 10.7 & 15.8 & 33.7 & 29.2 & 35.9 & 39.0 \\
\hline $\begin{array}{c}\text { Daisy } \\
\text { (Calendula officinalis) }\end{array}$ & & 36.2 & 44.8 & 48.9 & 49.7 & 55.1 & 63.3 & 47.8 & 61.2 & 73.4 \\
\hline $\begin{array}{c}\text { Demssisa } \\
\text { (Ambrosia maritime) }\end{array}$ & & 44.3 & 58.5 & 65.1 & 63.8 & 69.9 & 82.9 & 68.0 & 87.6 & 94.1 \\
\hline $\begin{array}{c}\text { Lemon grass } \\
\text { (Cymbopogon citrates) }\end{array}$ & & 29.1 & 32.2 & 39.2 & 31.6 & 36.0 & 40.1 & 45.0 & 52.5 & 61.5 \\
\hline $\begin{array}{c}\text { Marjoram } \\
\text { (Origanum majorana) }\end{array}$ & & 13.7 & 26.3 & 41.0 & 14.5 & 28.6 & 43.1 & 33.3 & 45.5 & 63.8 \\
\hline $\begin{array}{c}\text { Neem } \\
\text { (Azadrachta indica) }\end{array}$ & & 18.7 & 24.1 & 34.9 & 30.1 & 32.9 & 38.5 & 55.3 & 46.0 & 61.0 \\
\hline $\begin{array}{c}\text { Rosemary } \\
\text { (Rosmarinus officinalis) }\end{array}$ & & 5.8 & 11.4 & 15.2 & 30.4 & 38.5 & 38.3 & 32.0 & 39.3 & 36.7 \\
\hline $\begin{array}{c}\text { Thyme } \\
\text { (Thymus vulgaris) }\end{array}$ & & 27.8 & 33.4 & 45.8 & 30.4 & 37.0 & 46.9 & 45.5 & 50.9 & 69.3 \\
\hline $\mathrm{LSD}_{0.05}$ Intervals $(\mathrm{A})$ & 1.14 & & & & & & & & & \\
\hline LSD $_{0.05}$ Plants (B) & 1.78 & & & & & & & & & \\
\hline LSD $_{0.05}$ Concentration(C) & 0.83 & & & & & & & & & \\
\hline
\end{tabular}


Table (3): Effect of water extracts of some aromatic and medicinal water plants with three concentrations on egg hatching and hatching inhibition of root- knot nematode, Meloidogyne incognita after 72 hours of exposure period in vitro tests.

\begin{tabular}{|c|c|c|c|c|c|c|c|c|}
\hline \multirow{3}{*}{$\begin{array}{c}\text { Aromatic and medicinal } \\
\text { plants }\end{array}$} & \multicolumn{8}{|c|}{ Concentration $\%$} \\
\hline & \multicolumn{2}{|c|}{5} & \multicolumn{2}{|c|}{10} & \multicolumn{2}{|c|}{15} & \multicolumn{2}{|c|}{ Mean } \\
\hline & $\begin{array}{l}\text { No. eggs } \\
\text { hatching }\end{array}$ & $\begin{array}{c}\text { Inhibition } \\
\%\end{array}$ & $\begin{array}{l}\text { No. eggs } \\
\text { hatching }\end{array}$ & $\begin{array}{c}\text { Inhibition } \\
\%\end{array}$ & $\begin{array}{l}\text { No. eggs } \\
\text { hatching }\end{array}$ & $\begin{array}{c}\text { Inhibition } \\
\%\end{array}$ & $\begin{array}{l}\text { No. eggs } \\
\text { hatching }\end{array}$ & $\begin{array}{c}\text { Inhibition } \\
\%\end{array}$ \\
\hline $\begin{array}{c}\text { Camphor } \\
\text { (Eucalyptus globulus L.) }\end{array}$ & 30 & 54.89 & 25.5 & 61.65 & 20.75 & 68.80 & 25.42 & 61.78 \\
\hline $\begin{array}{l}\text { Camphor lemon } \\
\text { (Eucalyptus citriodora L.) }\end{array}$ & 13.75 & 79.32 & 11.5 & 82.71 & 9 & 86.47 & 11.42 & 82.83 \\
\hline $\begin{array}{c}\text { Chamomile } \\
\text { (Matricaria chamomilla L.) }\end{array}$ & 34.25 & 48.50 & 29 & 56.39 & 24 & 63.91 & 29.08 & 56.27 \\
\hline $\begin{array}{c}\text { Daisy } \\
\text { (Calendula officinalis L.) }\end{array}$ & 16.25 & 75.56 & 13.5 & 79.70 & 11.5 & 82.71 & 13.75 & 79.32 \\
\hline $\begin{array}{c}\text { Demssisa } \\
\text { (Ambrosia maritime L.) }\end{array}$ & 14.5 & 78.20 & 10.75 & 83.83 & 8.75 & 86.84 & 11.33 & 82.96 \\
\hline $\begin{array}{c}\text { Lemon grass } \\
\text { (Cymbopgon citratus L.) }\end{array}$ & 22 & 66.92 & 19.25 & 71.05 & 15 & 77.44 & 18.75 & 71.80 \\
\hline $\begin{array}{c}\text { Marjoram } \\
\text { (Origamum majorana L.) }\end{array}$ & 15 & 77.44 & 13.5 & 79.70 & 13 & 80.45 & 13.83 & 79.20 \\
\hline $\begin{array}{c}\text { Neem } \\
\text { (Azadrachta indica L.) }\end{array}$ & 21.25 & 68.05 & 17.25 & 74.06 & 14 & 78.95 & 17.50 & 73.68 \\
\hline $\begin{array}{c}\text { Rosemary } \\
\text { (Rosmarimus officinallis L.) }\end{array}$ & 45.75 & 31.20 & 36.50 & 45.11 & 28.5 & 57.14 & 36.92 & 44.49 \\
\hline $\begin{array}{l}\text { Thyme } \\
\text { (Thymus vulgaris L.) }\end{array}$ & 15 & 77.44 & 12.75 & 80.83 & 9.5 & 85.71 & 12.42 & 81.33 \\
\hline Control & 66.5 & & & & & & & \\
\hline LSD $_{0.05}$ Pants (A) & & & & & & & & \\
\hline LSD $_{0.05}$ Concentrations (B) & & & & & & & & \\
\hline $\mathrm{LSD}_{0.05} \mathrm{AB}$ & & & & & & & & \\
\hline
\end{tabular}


Similar results were obtained for the mortality\% at 48 and 72 hours of exposure periods for the same trend at 24 hours of exposure. At 48 hours of exposure treatment with application of $15 \%$ concentration, the highest mortality $\%$ of $\mathrm{J}_{2 \mathrm{~s}}$ was obtained in Demssisa leaves extract and the lowest extract showed in Chamomile leaves and flowers extract. Also, at 72 hours of exposure application treatment, the highest and lowest J2s mortality\% was found in Demssisa and Chamomile extracts, respectively. The mortality rate of $J_{2 s}$ significantly increased ( $P$ $\leq 0.05$ ) with increasing in exposure time within the all plant extracts tested. Demssisa leaves extract at $15 \%$ concentration immobilized (inhibited) $J_{2 s}$ by 65.1 , 82.9 and $94.1 \%$, and Camphor lemon leaves extract by $64.3,79.3$ and $89.7 \%$ after 24, 48 and 72 hours of exposure, respectively. On the other hand, Chamomile leaves \& flowers and Rosemary leaves extracts at the same concentration showed less mortality of $J_{2 s}$ than the other plant extracts within 24, 48 and 72 hours treatments.

Among water plant extracts tested after 72 hours of exposure treatment, the extract from Demssisa leaves showed the maximum $\mathrm{J}_{2 \mathrm{~s}}$ mortality\% (83.2\%), followed by Camphor lemon leaves extract $(75.8 \%)$ and Daisy leaves and flowers extract $(60.8 \%)$. On the other hand, Chamomile leaves and flowers Rosemary leaves and Camphor leaves extracts showed the minimum $\mathrm{J}_{2 \mathrm{~s}}$ mortality\% with an average of $34.7,36.0$ and $37.5 \%$, respectively, without significant differences among them.

In short, after 72 hours treatment application, both at 10 and $15 \%$ concentrations, the Demssisa and Camphor lemon leaves extracts recorded (87.6 \& $94.1 \%)$ and $(74.9 \& 89.7 \%) J_{2 s}$ mortality\%, respectively. However, the Daisy, Thyme, Marjoram, Neem, Lemon grass and Camphor extracts application at the $15 \%$ concentration observed $73.4,69.3,63.8,61.0,61.5$ and $56.1 \%, \mathrm{~J}_{2 \mathrm{~s}}$ mortality, respectively. Also, at the same concentration (15\%), the Chamomile and Rosemary extracts were recorded 39.0 and $39.3 \%$ only $\mathrm{J}_{2 \mathrm{~s}}$ mortality, respectively, when compared to the control treatment (about 3.3\% mortality).

From the average mortality of $\mathrm{J}_{2 \mathrm{~s}}$ of $M$. incognita after 72 hours of exposure period in the all tested water plant extracts in Table (2), the results revealed that Demssisa and Camphor lemon leaves extracts were highly toxic to the $\mathrm{J}_{2 \mathrm{~s}}$ of $M$. incognita, killing more than $85 \%$ of the $\mathrm{J}_{2 \mathrm{~s}}$, while the others gave quite low mortalities as shown in Table (2). Based on these findings, these water plant extracts were divided into four main groups i.e., 1- highly toxic ( $>85 \% \mathrm{~J}_{2 \mathrm{~s}}$ mortality) consisting of Demssisa leaves water extract at the 10 \& $15 \%$ concentrations (87.6 \& $94.1 \% \mathrm{~J}_{2 \mathrm{~s}}$ mortality, respectivelty) and Camphor lemon leaves water extract at $15 \%$ concentration (89.7\% J2s mortality), 2-toxic (70 - < 85\% $\mathrm{J}_{2 \mathrm{~s}}$ mortality) consisting of Camphor lemon leaves water extract at $10 \%$ concentration $(74.9 \%)$ and Daisy leaveas \& flowers water extract at $15 \%$ concentration $\left(73.4 \% \quad \mathrm{~J}_{2 \mathrm{~s}}\right.$ mortality), 3- 
moderately toxic (50 - $<70 \% \mathrm{~J}_{2 \mathrm{~s}}$ mortality) consisting of Demssisa and Camphor lemon leaves water extracts at $5 \%$ concentration, lemon grass and Thyme leaves water extracts at both the 10 and $15 \%$ concentrations, Daisy leaves \& flowers at $10 \%$ concentration and Camphor, Neem and Marjoram leaves water extracts at $15 \%$ concentration, 4 - lowly toxic ( $20-<50 \% \mathrm{~J} 2 \mathrm{~s}$ mortality) consisting of the rest water plant extracts treatments tested.

\section{Against egg hatching:}

Effect of water extracts of different aromatic and medicinal plants with different concentrations against eggs hatching of root- knot nematode, $M$. incognita larvae at $3^{\text {rd }}$ days exposure period are presented in Table (3).

The results revealed that all water plant extract treatments showed nematicidal activity by affecting the hatching of eggs of $M$. incognita root- knot nematode after 72 hours of exposure. The hatching of nematode eggs was observed to be varying in different concentrations in different plant extracts. The impact of plant extracts is concentration and plant species or type. The egg hatching rate was inversely proportional to concentration of plant extract, as concentration was decreased, toxicity was decreased resulting in correspondent decrease in inhibition \%, and minimum egg hatching inhibition rate (maximum egg hatching rate) was observed in distilled water $(0 \%$ concentration) as control treatment. There were significant differences $(P \leq 0.05)$ among different concentrations and among different plants (plant extracts) applied in number of infective juveniles per eggmass. Different water extracts of plants applied at different concentrations were inhibited $(P \leq 0.05)$ egg hatching to juveniles compared to distilled water (control treatment).

Among water plant extracts, extract obtained from Demssisa leaves showed minimum egg hatching rate (11.33 larvea/ eggmass), followed by Camphor lemon leaves extract (11.42), thyme leaves extract (12.42), Daisy leaves \& flowers extract (13.75) and Marjoram leaves extract (13.85 larvae/ eggmass), respectively, without significant differences among them. However, the maximum hatching rate of eggs (36.92 larvae/ eggmass) was recorded with Rosemary leaves extract, followed by chamomile leaves \& flowers extract (29.08) and Camphor leaves extract $(25.42$ larvae/ eggmass), respectively. The moderate egg hatching rate was obtained with leaves extract of both lemon grass and Neem plants with an average of 18.75 and 17.50 larvae/ eggmass, respectively, compared to distilled water (66.5 larvae/ eggmass). There were no significant difference between Lemon grass and Neem leaves water extracts. In general, the greatest inhibition percentage of egg hatching of $M$. incognita was recorded with Demssisa, Camphor lemon and Thyme leaves water extracts with an average of $82.96,82.83$ and $81.33 \%$, respectively, however, the lowest inhibition (44.49\%) was obtained by Rosemary leaves extract.

Among different concentration, all concentrations within all water plant 
extracts were inhibited significantly $(P \leq 0.05)$ egg hatching rate. The rate of egg hatching was decreased significantly with increasing concentration for each plant extract except, there were no significant differences among tested concentration (5, 10 and 15\%) in leaves extract of Marjoram plant only. The maximum hatching rate of eggs was observed in $5 \%$ concentration treatment, while, the minimum rate was at $15 \%$ concentration treatment in all water plant extracts tested. In general, water plant extracts applied at concentration of $15 \%$ was more effective than water extracts applied at both 10 and $5 \%$ concentrations on egg hatching. The least inhibition \% of egg hatching was obtained by Rosemary leaves water extract with an average of $31.20,45.11$ and $57.14 \%$ at 5,10 and $15 \%$ concentrations, respectively. Demssisa leaves, Daisy leaves \& flowers, Marjoram leaves, Thyme leaves and Camphor lemon leaves water extracts at $15 \%$ concentration reduce the egg hatching maximum (>80\%) over than control treatment ( $0 \%$ concentration). Both at 10 and $15 \%$ concentrations, the greatest percentage of egg hatching inhibition (83.83 and $86.84 \%$ ) was achieved by Demssisa leaves extract, followed by Camphor lemon (82.71 and $86.47 \%)$ and Thyme (80.83 and $85.71 \%$ ) leaves water extracts, respectively. On the other hand, Neem, Lemon grass, Camphor and chamomile leaves extracts were inhibited egg hatching by 78.95, 77.44, 68.80 and $63.91 \%$, respectively, at the $15 \%$ concentration.

The application of $15 \%$ concentration of water plant extracts revealed that Demssisa, Camphor lemon and Thyme leaves extracts were highly toxic against eggs hatching of $M$. incognita root- knot nematode, inhibiting more than $85 \%$ of the eggmass hatching, while, the others gave quite low egg inhibition (Table, 3). Based on these finding, these water plant extracts were divided into four main groups i.e. 1- highly toxic (> 85 egg inhibition) consisting of Demssisa (86.84\%), Camphor lemon $(86.47 \%)$ and Thyme $(85.71 \%$ egg inhibition) leaves water extracts, at $15 \%$ concentration, 2 - toxic (70 - < 85\% egg inhibition) consisting of Camphor lemon, Demssisa and Thyme leaves water extracts at 5 and $10 \%$ concentrations, Daisy leaves \& flowers and Marjoram leaves water extracts at all concentrations and lemon grass and Neem leaves water extracts at 10 and $15 \%$ concentrations, $3-$ moderately toxic (50 - < 70\% egg inhibition) consisting of Camphor leaves water extract at all concentrations, lemon grass and Neem leaves water extracts at $5 \%$ concentration, Rosemary leaves water extract at $15 \%$ concentration and Chamomile leaves \& flowers water extract at 10 \& 15\% concentrations, 4 - lowly toxic (30 - <50\% eggs inhibition) consisting of the rest of the water plant extract treatments tested.

Our results showed that all the water extracts of aromatic and medicinal plants tested significantly increased $(P \leq 0.05)$ the $J_{2 s}$ mortality and eggmass hatching of $M$. incognita root- knot nematode after 72 hours of exposure. Eggmass hatching and $J_{2 s}$ mortality increased with increase concentration of all the extracts. $\mathrm{J}_{2 \mathrm{~s}}$ mortality increased corresponding to an increased time of exposure. A similar 
results were reported by Elbadri et al. (2008); Kumari \& Devi, (2013); Feyisa et al. (2015); Patikar et al. (2016) and Singh et al. (2017). The Demssisa ( $A$. maritime), Camphor lemon (E. citroidora) and Thyme ( $T$. vulgaris) extracts were more suppressive at level (concentration) of $15 \%$. Some investigators indicated that the toxic of plants may be due to toxic effects of certain compounds. Demssisa plant includes thogene, flanders, glicocin, lambrosen, arthimin (Gad- El- Rab, 2000). The application terpene aldehyde citronallal was the major component found in Camphor Lemon. Relatively small amounts of other monoterpenoids such as isopulegal, citronellal and citronellyl format were also detected in this plant (Laqual et al., 2015). The Thyme plant was found to contain thymal is monoterpenoid phenol as the dominat comound, together with very small amounts of other monoterpenoid constituents as carvacrol eugenol, linalool (Ibrahim et al., 2006 and Kong et al., 2007).

The impact of water extracts of aromatic and medicinal plants against rootknot nematodes, Meloidogyne species has been reported by several investigations. Ibrahim et al. (2006) reported that the extracts of pure components carvacrol, thynol and linallol at 1,2 and $4 \mathrm{mg} / \mathrm{L}$ concentrations were the most toxic against $M$. incognita $\mathrm{J}_{2 \mathrm{~s}}$ followed by terpinal and menthone. Hatching eggs was completely inhibited at high concentrations $(2,4 \mathrm{mg} / \mathrm{L}$.) of carvacrol, thynol and linalool compounds. Khalil and Shawky et al. (2008) found that water leaf extracts of Demssisa ( $A$. anaritima) was obviously redction $M$. javanica final population and build up, Nimbal Kar and Rojurkar (2009) reported that $100 \%$ concentration of root extracts of Neem and Lemon grass at 100\% concentration exhibited 100 \& 95\% inhibition of eggs hatching 7 days after treatment and $100 \& 75 \%$ larval mortality after 48 hours of exposure, respectively of Meloidogyne species.

One the other hand, Wiratno et al. (2009) found that Neem and Lemon grass extracts were not toxic on $\mathrm{J}_{2 \mathrm{~s}}$ of $M$. incognita after 24 hours of exposure period. In among treatments of Rape seed \& leaf, Africana marigold leaf Neem leaf and Nemm seed water extracts Feyisa et al. (2015) found that the Neem seed extract more significantly inhibited eggs hatching (after 7 days of exposure) and $J_{2 s}$ mortality (after 72 hours of exposure) of $M$. incognita at the $10 \%$ concentration, followed by Lantana, Africana marigold, Rape and Neem Leaf extracts, respectively. Also, the aqueous extracts of Camphor and Neem when applied at $10 \%$ concentration suppressed $\mathrm{J}_{2 \mathrm{~s}}$ of Meloidogyne species by $100 \& 91 \%$, respectively (Salim et al., 2016). On the other side, Shawky et al. (2016) found that the Demssisa and Camphor as aqueous extracts had a significant effect in reducing final population and build up of $M$. incognita, and Camphor extract was the least effective treatment. Maximum mortality in $\mathrm{J}_{2 \mathrm{~s}}$ of $M$. incognita was observed in lemon grass water extract at 5000 ppm concertration after 24 hours of exposure while, the minimum cumulative eggs hatching was found at 1000 ppm concentration after 16 days of exposure Patidar et al. (2016). Bajestani et al. (2017) reported that in 
among treatments of medicinal plant extracts (Marigold, Resomary and nigella), Resomary extract has the greatest impact on the reduction of $M$. incognita at $40 \%$ concentration.

\section{Conclusion:}

It has been concluded from present study that certain water plant extracts showed nematicidal potential in the management of $M$. incognita among the tested extracts, the leaf powder extracts of Demssisa, Camphor Lemon and Thyme at the rate of $15 \%$ were highly toxic to the nematodes, killing and inhibiting more than $85 \%$ of the $\mathrm{J}_{2 \mathrm{~s}}$ and eggs hatching. The use of these plant extracts may be one of the efficient alternatives and cheep methods of nematode control that are need of the hour and safe to farmers as well as environment. These may be replacement to the synthetic dangerous and expensive chemical in future.

\section{References}

Abbott, W. S. (1925). A method of computing the effectiveness of an insecticide. J. Econ. Entomol., 18: 265- 267.

Bajestani, M. S.; K., Dolatabadi and E. Mahdi khani- Moghadam (2017). Effect of medicidal plant extracts on inoculated Meloidogyne incognita in tomato. Pak. J. Nematal., 35 (1): 73- 78.

Barker, T. R. (1985). Nematode extraction and bioassays, pp. 19- 35, In: An Advanced Treatise on Meloidogyne. Barker T. R., Cater c. c. and Sasser, J. N. (eds). North Carolina State University, USA.

Elbadri, G. A. A. D.; W., Lee; J. C., Park; H. B., Yu and H. Y., Choo (2008). Evaluation of various plant extracts for their nematicidal efficacies against juveniles of Meloidogyne incognita. J. Asia- Pacific entmol. 11: 99- 102.

Feyisa, B.; A., Lencho; T., Selvaraj and G., Getaneh (2015). Evaluation of some botanicale and Trichoderma harzianum for the management of tomato rootknot nematode (Meloidogyne incognita) (Kofoid and White Chit Wood). Adv. Crop. Sci. Tech., 4 (1): 1- 10.

Gad- el- Rab, s. M. (2000). Studies on the effect of demssisa dry matter (Ambrosia manitima L.) as nutural material to control nematodes of plastic- houses cucumber in Egypt. J. Hort., 27: 373- 383.

Gomez, K. W. and A. A., Gomez (1984). Statistical procedures for agricultural research, $2^{\text {nd }}$ Ed. John Witley and Sons, New York p. 680.

Ibrahim, S. K.; A. F., Traboulsi and S., El- Haj (2006). Effect of essential oils and plant extracts on hatching, migration and mortality of Meloidogyne incognita. Phytopathl. Medit., 45 (3): 238- 246. 
Khalil, A. E. and M. Samaa, Shawky (2008). Combination of the nematophagous fungus Paecilomyces Lilacinus and aqueous leaf extracts in controlling Meloidogyne Javanica infecting potato. Egypt. J. Agronematol., 6 (2): 185196.

Khan, Z. and Y. H., Kin (2007). A review on the role of predatory soil nematodes in the biological control of plant parasitic nematodes. Appl. Soil Ecol., 35 (2): 370- 379 .

Khayyat, F.; E., mahdikhani- Moghadam; h. Roohani and m., Azizi (2014). Survey in nematicide activity of eucalyptus, coma and galbanum essence on the root- knot nematode, Meloidogyne incognita in laboratory conditions. J. PI. Production, 28: 338- 345.

Kong, J. O.; S. M., Lee; Y. S., Moon; S. G., Lee and Y. J., Ahn (2007). Nematicidal activity of cassia and cinnamon oil compounds and related compounds toward Bursaphelenchus Xylophilus (Nematode: Parasitaphelenchidae). J. nematal. 39: 31- 36.

Kumari, N.V. and M.L. Devi, (2013). Effect of some indigenous plant extracts on the inhibition of egg hatching of nematode Meloidogyne incognita Chitwood infesting mulberry. HortFlora Res. Spectr.: 2(1):35-39.

Laquale, S.; V., Candido; P., Avado; M. R., Argentier and T. D., Addabbo (2015). Esrential oils as soil biofumigants for the control of the root- knot nematode Meloidogyne incognita on tomato. Ann. Appl. Boil., 167: 217224.

Maareg, M. F.; I. M. A., Gohar and G. H., Rady (2005 a). Predatory behavior of some soil mites towards root- knot nematode, Meloidogyne incognita infecting sugarbeet crop. Egypt. J. Agric. Res., 83 (2): 527- 537.

Maareg, M. F.; S. F., Tawfik and I. M. A., Gohar (2005 b). Effect of split and amount application of nitrogen fertilizer to sugarbeet on root- knot nematode, Meloidogyne Javanica and Crop production under sprinkler irrigation in sandy soil. Egypt. J. Agric. Res., 83 (2): 687- 706.

Maareg, M. F.; S. F., Tawfik and I. M. A., Gohar (2007). Effect of some intercropping system of garlic and onion with sugarbeet on their yields and associated nematode, Meloidogyne Javanica. The third Conf. of sustain. Agric. Develop. Fac. Agric., Fayoum Univ., 12- 14 Nov., 487- 506.

Mousa, E. M.; M. E., Mahdy and Dalia, M., Younis (2011). Evaluation of some plant extracts to control root- knot nematode, Meloidogyne spp. on tomato plants. Egypt. J. agronematol., 10: 1- 14. 
Nimbalkar, R. K. and S. K., Rojurkar (2009). Effect of plant root extracts to control root- knot nematode (Meloidogyne spp.) of soybean (Glucin max) Biol. Forum- An Int. J., 1 (1): 65- 68.

Okada, H. and H., Hadara (2007). Effect of tillage and fertilizer on nematodes communities in a japanese soybean field. Appl. Soil. Ecol., 35 (3): 582- 598.

Patidar, R. K.; D. San; M., Pathak; R. C., Shakywar and Rajesh, K. Patidar (2016). Effect of essential oils on mortality, chatching and multiplication of root- knot nematode, Meloidogyne incognita and its impact on plant growth parameters. Int. J. Agric. Environ. \& Biotech., 9 (5): 887- 895.

Salim, H. A.; Iman, S., Salman; I. I., Majeed and H. H., Hussein (2016). Evaluation of some plant extracts for their nematicidal properties against root- knot nematode, Meloidogyne spp. J. Gent. Environ. Conserv., 4 (3): 241- 244.

Singh, N. G.; A., Kumar; S. Ram and V. Kumar (2017). Evaluation of nematicidal activity of ethanolic extracts of medicinal plants to Meloidogyne incognita (kofoid and white) chitwood under lab conditions. Int. J. Pure App. Biosci. $5(1): 827-831$.

Shawky, Samaa, M.; Ahlam, Al- Ghonaimy and Enean, A., Hammad (2016). Efficacy of some bioagents, Algal species and plant extracts in controlling Meloidogyne incognita on yield of grap vines in Egypt. Egypt. J. Agronematal., 15 (1): 79- 94.

Wesemael, W.M.L; N., Viaene and M. Moens (2010). Root-knot nematodes (Meloidogyne spp.) in Europe, Nematol., 13: 3-16.

William Son, V. M. and A., Kumar (2006). Nematode resistance in plants. The battle underground. Trends Genet. 22 (7): 396- 403.

Wirando, D., Tanwiryons; H., Van den Berg; J. A. G., Riksen; I. M. C. M., Rietjens: S. R., Djiwanti; J. E., Kammenga and A. I. Murk (2009). Nematicidal actively of plant extracts against the root- knot nematode, Meloidogyne incognita. The open nutural Products J., 2: 77- 85.

Youssef, M. M. A.; Wafaa, M. A., El-Nagdi; and Mona G. Dawood (2015). Population density of root-knot nematode, Meloidogyne incognita infecting eggplant as affected by medicincal plant aqueous extracts. App. Sci. Report., 10(1):8-11. 


\section{كفاءة المستخلصات المائية لبعض النباتات العطرية والطبية ضد يرقات وفقس}

\section{البيض لنيماتودا تعقد الجذور النوع ميلويدوجين انكوجنيتا تحت ظروف المعمل.}

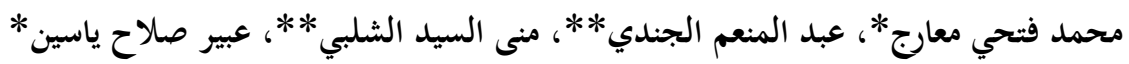
* قسم وقاية النباتات، معهد بحوث المحاصيل السكرية، مركز البحوث الزراعية، جيزة، مصر.

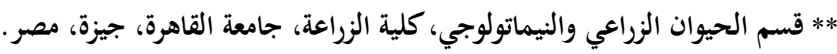

\section{الملخص العربي}

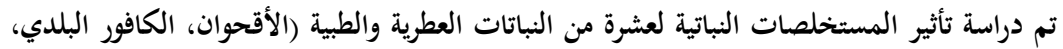
الكافور الليمون، البردقوش، الدمسيسة، حشيشة الليمون، النيم، شيح البابونج، حصالبان، الزعتر)

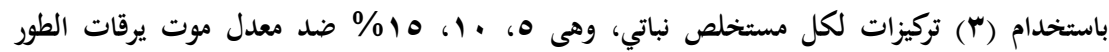

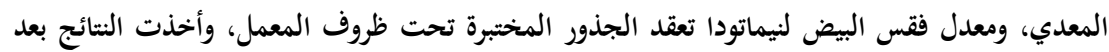

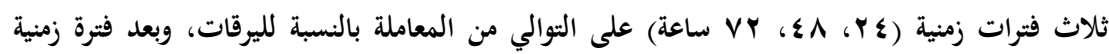
واحدة (ثلاثة أيام) بالنسبة لمعاملة أكياس البيض. (ناء

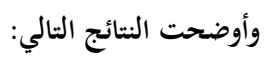

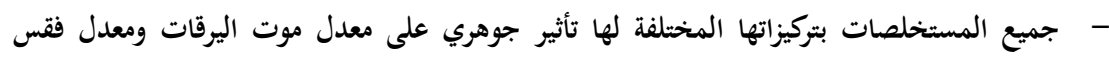

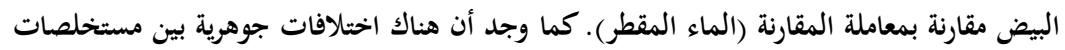

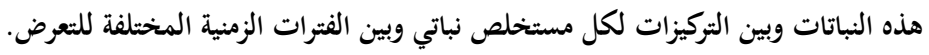

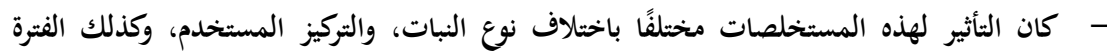

$$
\text { الزمنية لمعاملة النيماتودا بالمستخلص. }
$$

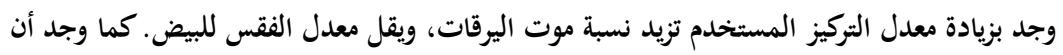
نسبة موت اليرقات تزيد مع زيادة فترة تعرضها لكل تركيز .

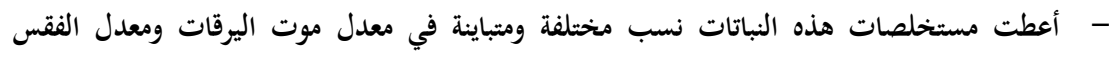

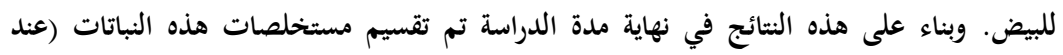
التركيز ه 1\%) إلى أربع مجاميع رئيسية من حيث درجة سميتها للنيماتودا (مجموعة شديدة السمية، مداء مجموعة سامة، مجموعة متوسطة السمية، مجموعة منخفضة السمية).

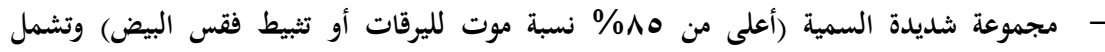

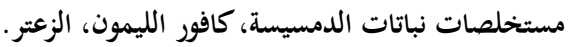

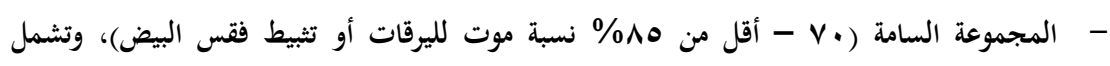
مستخلصي نباتات البردقوش والأقحوان. - أما مجموعتي المستخلصات متوسطة السمية ومنخفضة السمية تضم باقي المستخلصات النباتية الأخرى تحت الدراسة. ومن هذه النتائج يمكن استخدام المستخلصات النباتية شديدة السمية والسامة في مكافحة نيماتودا

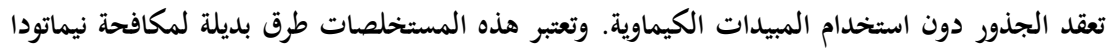

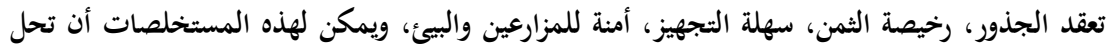




$$
\text { المحلكاملة للنيماتودات الكيماوية شديدة الخطورة وعالية الثمن مستقبلاً كما يمكن إدخالها في برامج المكافحة }
$$

